\title{
Penyuluhan dan Pengetahuan Tentang Pernikahan Usia Muda
}

\section{Counseling and Knowledge of the Young Age Marriage}

\author{
Rufaida Nurjanah, Dwiana Estiwidani, Yuliasti Eka Purnamaningrum
}

\section{Jurusan Kebidanan Politeknik Kesehatan Kementerian Kesehatan Yogyakarta}

\begin{abstract}
Abstrak
Pada tahun 2010 - 2012, di Kabupaten Gunungkidul, terjadi kenaikan dua kali lipat kasus pernikahan di bawah umur. Kasus tertinggi terdapat di Kecamatan Patuk, yaitu sebanyak 18 kasus. Kehamilan di usia muda berkorelasi dengan angka kematian ibu. Peningkatan pengetahuan kesehatan reproduksi dapat dilakukan dengan penyuluhan. Tujuan penelitian ini untuk mengetahui pengaruh penyuluhan terhadap peningkatan pengetahuan tentang pernikahan usia muda. Jenis penelitian yang digunakan adalah kuasi eksperimen dengan pretest-posttest terhadap kelompok kontrol. Penelitian dilakukan di SMPN 1 Patuk. Subjek penelitian adalah siswa kelas VIII. Jumlah sampel sebanyak 25 responden, baik pada kelompok eksperimen maupun kontrol. Instrumen penelitian adalah kuesioner. Hasil pretest menunjukkan nilai rata-rata kelompok eksperimen adalah 70,40 dan kelompok kontrol adalah 71,20 . Hasil posttest menunjukkan nilai rata-rata kelompok eksperimen adalah 90,88 dan kelompok kontrol adalah 78,40 . Terdapat perbedaan yang signifikan antara nilai pretest dengan posttest. Peningkatan pengetahuan pada kelompok eksperimen sebesar 20,48 , sedangkan kelompok kontrol sebesar 7,20 . Hasil uji independen sampel uji t menghasilkan nilai p $0,000(<0,05)$. Penelitian ini menyimpulkan bahwa ada pengaruh penyuluhan terhadap peningkatan pengetahuan tentang pernikahan usia muda pada siswa kelas VIII di SMPN 1 Patuk tahun 2013

Kata kunci: Pengetahuan, penyuluhan, pernikahan usia muda.
\end{abstract}

\section{Abstract}

In 2010-2012, the amount of underage marriage had doubled in Gunung Kidul. Moreover, the highest case was in Patuk which had 18 cases. However, there was correlation between early pregnancy and maternal mortality. Improving the knowledge of reproductive health can be done by counseling. The research was aimed to find out about the effect of counseling on the improvement of the knowledge of young age marriage. The research was categorized into quasi experimental research which has pre-posttest with control group design. The research was conducted at SMPN 1 Patuk. The subject of the research was VIII grade students. There were 25 respondents both the experiment group and control group as well. The instrument used was questioner. The result of pretest was the average score of experiment group was 70.40 while control group's average score is 71.20 . The result of the posttest was the average score of experiment group was 90.88 while the control group's average score was 78.40 . So, it could be concluded that there were a significant difference between pretest and posttest. The knowledge of experiment group increased by 20.48 whiles the control group's knowledge increased by 7.20 . The result of independent sample t-test was the score of $p$-value is $0.000(<0.05)$. This research concludes that there is effect of counseling on the improvement of the knowledge about young age marriage of VIII grade students of SMPN 1 Patuk in 2013.

Keywords: Knowledge, counseling, young age marriage

\section{Pendahuluan}

Indonesia memiliki jumlah penduduk terbesar keempat di dunia. Badan Pusat Statistik memproyeksikan jumlah penduduk Indonesia tahun 2010 sekitar 234,2 juta jiwa. Namun, hasil Sensus Penduduk (SP) 2010 menunjukkan sekitar 3,5 juta lebih besar dari proyeksi. Laju pertumbuhan penduduk yang diproyeksikan terus menurun menjadi sekitar 1,27\% tetapi pada SP 2010 tercatat sebesar $1,49 \% .^{1}$ Sasaran pengendalian kuantitas penduduk yang tidak memenuhi harapan ini tidak terlepas dari melemahnya Program Keluarga Berencana Nasional. Terbukti dari statisnya total fertility rate (TFR) sebesar 2,6 anak per wanita pada dua Survei Demografi dan

Alamat Korespondensi: Yuliasti Eka Purnamaningrum, Jurusan Kebidanan Poltekkes Kemenkes Yogyakarta, Jl. Mangkuyudan MJ III/304 Yogyakarta 55143, Hp.081328223177, e-mail: yuliasti.eka.purnamaningrum@gmail.com 
Kesehatan Indonesia (SDKI) terakhir yaitu tahun 2002 dan 2007. ${ }^{1}$ Berdasarkan hasil SDKI 2012, TFR masih berada pada angka 2,6 anak per wanita padahal target yang diharapkan pada tahun 2012 sebesar 2,1 anak per wanita. ${ }^{2}$ Fertilitas merupakan salah satu faktor yang menyebabkan pertambahan jumlah penduduk. Fertilitas dipengaruhi oleh usia perkawinan pertama, aborsi, tingkat pendidikan, dan status sosial ekonomi. ${ }^{3}$ Usia perkawinan pertama (UKP) adalah indikator dimulainya seorang perempuan berpeluang untuk hamil dan melahirkan. Permasalahan kesehatan pada perempuan di Indonesia berawal dari masih tingginya usia perkawinan pertama di bawah usia 20 tahun, yaitu $41,9 \%$ pada usia $15-$ 19 tahun dan $4,8 \%$ pada usia 10 - 14 tahun. 4

Indonesia adalah negara dengan pernikahan usia muda tinggi di dunia (rangking 37) serta tertinggi kedua di ASEAN setelah Kamboja. ${ }^{5}$ Kehamilan di usia yang sangat muda berkorelasi dengan angka kematian dan kesakitan ibu. Anak perempuan berusia $10-14$ tahun berisiko lima kali lipat meninggal saat hamil maupun bersalin dibandingkan kelompok usia 20 - 24 tahun, sementara risiko ini meningkat dua kali lipat pada kelompok usia 15 - 19 tahun. Pernikahan pada usia muda meningkatan risiko terjadinya keguguran, obstetric fistula, kanker leher rahim dan berbagai masalah lainnya. Pernikahan di usia muda juga dapat menyebabkan gangguan perkembangan kepribadian dan menempatkan anak yang dilahirkan berisiko terhadap kejadian kekerasan, keterlantaran, keterlambatan perkembangan, kesulitan belajar, gangguan perilaku, dan cenderung menjadi orangtua pula di usia dini. Konsekuensi yang luas dalam berbagai aspek kehidupan akan menjadi hambatan dalam mencapai tujuan Millennium Developmental Goals. ${ }^{6}$

Hasil Survei Kesehatan Reproduksi Remaja Indonesia 2002 - 2003, menjelaskan bahwa penentu keputusan pasangan menikah adalah diri sendiri $(63 \%$ pada perempuan dan $72 \%$ pada laki-laki), orangtua dan diri sendiri (33\% pada perempuan dan $25 \%$ pada laki-laki), serta orangtua saja (4\% pada perempuan dan $3 \%$ pada laki-laki). ${ }^{7}$ Badan Kependudukan dan Keluarga Berencana Nasional (BKKBN) telah menetapkan program yang bertujuan mengendalikan jumlah penduduk yaitu Pendewasaan Usia Perkawinan (PUP) adalah upaya meningkatkan usia pada perkawinan pertama, sehingga mencapai usia minimal pada saat perkawinan yaitu 20 tahun bagi wanita dan 25 tahun bagi pria. ${ }^{1}$

Pada tahun 2007 - 2012 terjadi kenaikan TFR sebesar 0,3 di Provinsi Daerah Istimewa Yogyakarta (DIY). Pada tahun 2007, TFR DIY berada pada angka 1,8. Pada tahun 2010 naik menjadi 1,94 dan berdasarkan hasil SDKI 2012 TFR DIY naik menjadi 2,1.8,9 Data Statistik Kesejahteraan Rakyat DIY 2011 menunjukkan 25,71\% perempuan di DIY menikah pada usia di bawah 18 tahun (2,84\% di bawah usia 16 tahun). Kejadian tertinggi per- nikahan di bawah usia 16 tahun terdapat di Kabupaten Gunungkidul yaitu sebesar 3,53\%. Masalah lain yang terjadi adalah 36,49\% wanita Gunungkidul juga menikah di bawah usia 18 tahun. $^{3}$

Berdasarkan data dari Kementerian Agama Kantor Wilayah DIY, terjadi kenaikan dua kali lipat atau 100\% kasus pernikahan di bawah umur di Kabupaten Gunungkidul. ${ }^{10}$ Jumlah pernikahan di bawah umur pada tahun 2010 sebanyak 54 orang, tahun 2011 sebanyak 96 orang dan pada tahun 2012 sebanyak 108 orang. Pada tahun 2011, kasus pernikahan di bawah umur tertinggi terdapat di Kecamatan Patuk yaitu 18 kasus dengan persebaran kasus terjadi hampir merata di setiap desa. Berdasarkan data dari Kantor Urusan Agama (KUA) Kecamatan Patuk, kenaikan persentase pernikahan di bawah usia 21 tahun terjadi di wilayah kecamatan Patuk bagian Barat meliputi Desa Salam, Patuk, Pengkok, dan Semoyo. ${ }^{11}$ Selama tiga tahun terakhir terjadi peningkatan kejadian pernikahan di bawah usia 21 tahun yaitu pada tahun 2010 sebesar $31,8 \%$, tahun 2011 sebesar 41,9\%, dan tahun 2012 naik menjadi 44,5\%. Hal ini menunjukkan kecenderungan pernikahan usia muda yang tinggi di Kecamatan Patuk bagian barat.

Studi pendahuluan yang dilakukan peneliti di KUA Kecamatan Patuk pada bulan Maret 2013 mengenai data perempuan dan laki-laki yang menikah di bawah umur 21 tahun pada tahun 2012 di wilayah Patuk bagian barat, dari 9 orang terdapat 6 orang $(67 \%)$ yang menikah dengan pendidikan terakhir SMP khususnya berasal dari SMPN 1 Patuk. Hasil studi pendahuluan yang dilakukan peneliti di SMPN 1 Patuk pada bulan Februari 2013, belum pernah ada penyuluhan tentang pernikahan usia muda. Penelitian ini bertujuan untuk mengetahui pengaruh penyuluhan terhadap peningkatan pengetahuan tentang pernikahan usia muda pada siswa kelas VIII SMPN 1 Patuk tahun 2013.

\section{Metode}

Penelitian ini merupakan penelitian kuasi eksperimen dengan pre-posttest dengan kelompok kontrol dilakukan di SMPN 1 Patuk pada tanggal 11 Mei 2013. Populasi dalam penelitian ini adalah seluruh siswa kelas VIII SMPN 1 Patuk. Teknik pengambilan sampel menggunakan purposive sampling, dan didapatkan sampel minimal dengan menggunakan rumus besar sampel untuk uji hipotesis terhadap rerata dua populasi yaitu sejumlah 25 orang untuk masing-masing kelompok. Bahan yang digunakan untuk kelompok eksperimen pada penelitian ini adalah file powerpoint yang berisi materi penyuluhan pernikahan usia muda dan video iklan pendewasaan usia perkawinan yang didapatkan dari website BKKBN. Kelompok kontrol diberikan selebaran yang berisi materi penyuluhan pernikahan usia muda. Instrumen pengumpulan data menggunakan kuesioner. Jenis data 
dalam penelitian ini adalah data primer. Teknik pengumpulan data pada kelompok eksperimen diawali dengan pretest kemudian diberikan penyuluhan selama $1 \mathrm{x}$ 60 menit. Posttest dilakukan 20 menit setelah penyuluhan. Pada kelompok kontrol diawali dengan pretest kemudian diberikan selebaran tentang pernikahan usia muda. Posttest dilakukan 20 menit setelah pemberian selebaran. Analisis data menggunakan uji beda dua sampel berpasangan dan uji beda dua kelompok saling bebas.

\section{Hasil}

Hasil uji homogenitas untuk karakteristik usia responden, didapatkan nilai p sebesar 0,412 (nilai p > 0,05) yang berarti bahwa kedua kelompok memiliki karakteristik usia yang sama sehingga karakteristik yang sudah dimiliki responden sebelumnya tidak akan memengaruhi hasil penelitian. Jadi, dapat ditarik kesimpulan bahwa kedua kelompok tersebut homogen. Sebagian besar responden berusia 14 tahun yaitu $48 \%$ pada kelompok eksperimen dan 52\% pada kelompok kontrol (Tabel 1).

Berdasarkan uji normalitas data, diketahui bahwa nilai $p>0,05$ maka data berdistribusi normal. Hasil uji homogenitas nilai pretest kedua kelompok, diketahui bahwa nilai $p$ sebesar 0,803 (nilai $p>0,05$ ) yang berarti nilai pretest kedua kelompok tersebut homogen. Uji hipotesis dengan tingkat kepercayaan 95\% bertujuan untuk mengetahui pengaruh penyuluhan terhadap peningkatan pengetahuan tentang pernikahan usia muda. Terdapat perbedaan yang signifikan antara nilai pretest dengan posttest (nilai $\mathrm{p}<0,05$ ), menunjukkan peningkatan pengetahuan kelompok eksperimen dan kontrol (Tabel 2).

Hasil uji beda dua kelompok saling bebas menyatakan perbedaan peningkatan pengetahuan yang signifikan antara kelompok eksperimen dan kelompok kontrol dengan nilai $p$ sebesar 0,000 (nilai $p<0,05$ ), sehingga dapat disimpulkan bahwa ada pengaruh penyuluhan terhadap peningkatan pengetahuan tentang pernikahan usia muda pada siswa kelas VIII SMPN 1 Patuk tahun 2013. Rerata peningkatan nilai pada kelompok eksperimen adalah 20,48, sedangkan pada kelompok kontrol adalah 7,20 . Selisih rerata peningkatan pengetahuan antara kelompok eksperimen dan kelompok kontrol adalah 13,28 (Tabel 3).

\section{Pembahasan}

Penyuluhan adalah salah satu bentuk promosi kesehatan yang sederhana dan dapat mencakup sasaran yang luas. Penyuluhan kesehatan memberikan dan meningkatkan pengetahuan yang selanjutnya dapat memengaruhi sikap dan perilaku memelihara dan meningkatkan kesehatan masyarakat. Salah satu luaran awal dari kegiatan penyuluhan adalah peningkatan pengetahuan. ${ }^{12}$ Penyiapan sumber daya manusia dalam mewujudkan keluarga
Tabel 1. Distribusi Responden Berdasarkan Usia

\begin{tabular}{llllll}
\hline & \multicolumn{5}{c}{ Kelompok } \\
\cline { 2 - 4 } Karakteristik Usia & \multicolumn{2}{c}{ Eksperimen } & \multicolumn{2}{c}{ Kontrol } & \multirow{2}{*}{ Nilai p } \\
\cline { 2 - 4 } & $\mathbf{n}$ & $\%$ & $\mathbf{n}$ & $\%$ & \\
\hline 13 tahun & 7 & 28 & 9 & 36 & \multirow{2}{*}{0,412} \\
14 tahun & 12 & 48 & 13 & 52 & \\
15 tahun & 6 & 24 & 3 & 12 & \\
\hline
\end{tabular}

Tabel 2. Beda Rerata Nilai Pretest dan Posttest Tentang Pernikahan Usia Muda pada Kelompok Eksperimen dan Kelompok Kontrol

\begin{tabular}{lccccccc}
\hline & \multicolumn{3}{c}{ Pretes } & \multicolumn{3}{c}{ Posttest } & \multirow{2}{*}{ Nilai p } \\
\cline { 2 - 6 } Kelompok & Mean & SD & Selisih & Mean & SD & Selisih & \\
\hline Eksperimen & 70,40 & 11,4 & 1,20 & 90,88 & 6,9 & 12,48 & $0,000^{*}$ \\
Kontrol & 71,20 & 11,1 & & 78,40 & 10,1 & & $0,000^{*}$ \\
\hline
\end{tabular}

Tabel 3. Beda Rerata Peningkatan Pengetahuan Tentang Pernikahan Usia Muda pada Kelompok Eksperimen dan Kelompok Kontrol

\begin{tabular}{lllllll}
\hline Kelompok & Mean & SD & Selisih & T & Nilai p & 95\% CI \\
\hline $\begin{array}{lllll}\text { Eksperimen } \\
\text { Kontrol }\end{array}$ & 20,48 & 3,6 & 13,28 & 6,498 & $0,000 \%$ & $9.107-17.453$ \\
\hline
\end{tabular}

berkualitas pada masa depan harus dilakukan sejak remaja. Peningkatan pemahaman kesehatan reproduksi remaja dapat dilakukan dengan promosi kesehatan yang bersifat pencegahan. Penyuluhan merupakan bentuk promosi kesehatan sederhana yang dapat mencakup sasaran luas. Ceramah di dalam penyuluhan merangsang pikiran dan dikombinasikan dengan dialog antara pemberi ceramah dan audiens. ${ }^{13}$

Ada perbedaan yang signifikan rerata peningkatan nilai antara kelompok eksperimen dengan kelompok kontrol yang menunjukkan pengaruh penyuluhan terhadap peningkatan pengetahuan. Penelitian terdahulu menemukan pelaksanaan penyuluhan menggunakan metode ceramah bersifat rasional sebagai unsur proses pendidikan yang meningkatkan pengetahuan. ${ }^{14}$ Metode penyuluhan tersebut dapat dijadikan alternatif pelaksanaan pendidikan kesehatan untuk meningkatkan pengetahuan siswa tentang pernikahan usia muda. Selain itu, pendidikan kesehatan reproduksi dengan penyuluhan berbasis sekolah efektif mengurangi risiko dan perilaku negatif di kalangan remaja akibat kurang pemahaman. ${ }^{15,16}$ Hambatan remaja memanfaatkan pelayanan kesehatan reproduksi adalah perasaan malu, takut dengan orang tua dan masyarakat, fasilitas kurang lengkap, sikap tidak bersahabat petugas, pengetahuan dan informasi kesehatan reproduksi remaja kurang. ${ }^{17,18}$ Selain itu, faktor penghambat remaja memanfaatkan pelayanan kesehatan reproduksi adalah faktor fisik, faktor proses, dan fakor psikososial. ${ }^{19}$ 
Sebagian besar responden kelompok eksperimen dan kontrol mempunyai usia yang sama, seluruh responden adalah siswa kelas VIII dengan rentang umur $13-15$ tahun. Usia merupakan salah satu faktor yang memengaruhi tingkat pengetahuan termasuk daya tangkap dalam penerimaan materi yang diberikan. Hal tersebut berhubungan dengan kesiapan organ menerima materi pada usia reproduksi dan mulai melemah penerimaan materi seiring dengan pertambahan usia. ${ }^{20}$ Sebagian besar responden kelompok eksperimen dan kontrol berusia 14 tahun sehingga merupakan waktu yang tepat untuk mulai memberikan pendidikan kesehatan reproduksi. WHO menekankan pendidikan kesehatan reproduksi mulai diberikan kepada remaja muda yang berumur 10 - 14 tahun yang merupakan masa emas pembentukanya landasan kesehatan reproduksi yang kuat. ${ }^{21}$ Perkembangan kognitif operasional formal juga berada pada usia 12 tahun atau lebih sehingga remaja telah mampu memproses informasi ketika mendapatkan pendidikan kesehatan. ${ }^{22}$

Pada penelitian ini, kelompok kontrol mendapat intervensi selebaran sebagai etika penelitian untuk keadilan dan keterbukaan. Selebaran merupakan salah satu alat peraga pendidikan kesehatan yang hanya dapat diamati dengan indra penglihatan, sehingga membutuhkan kemandirian siswa untuk memahami pesan pada selebaran. Nilai pengetahuan pada kelompok kontrol meningkat sebesar 7,20. Kelompok eksperimen mendapat intervensi penyuluhan pernikahan usia muda dengan materi yang disampaikan menggunakan berbagai media antara lain slide powerpoint, LCD, laptop, speaker, dan video iklan pendewasaan usia perkawinan. Penyuluhan juga menggunakan metode ceramah tanya jawab sehingga ada komunikasi antara pemberi materi dan penerima materi. Penelitian menemukan peningkatan nilai pengetahuan pada kelompok eksperimen sebesar 20,48.

Keuntungan penyuluhan dengan metode ceramah adalah mudah digunakan, dapat memengaruhi pendapat, merangsang pikiran dengan kritis, dan dapat dikombinasi kan dengan dialog antara pemberi ceramah dan audiens. Efektivitas penggunaan ceramah dapat ditingkatkan apabila digabung dengan program audiovisual yang mendukung. ${ }^{13}$ Penyuluhan pada kelompok eksperimen memungkinkan audiens menggunakan lebih dari satu indra.

Nilai pengetahuan pada kelompok kontrol meningkat lebih kecil daripada kelompok eksperimen karena hanya melibatkan indra penglihatan. Selain itu, materi yang terdapat pada selebaran terbatas dan lebih ringkas daripada materi yang didapatkan kelompok eksperimen melalui penyuluhan. Hal tersebut sesuai dengan teori kerucut Edgar Dale yang menyusun fungsi alat peraga berdasarkan prinsip pengetahuan pada manusia diterima melalui panca indra dan dipengaruhi oleh intensitas alat peraga yang berbeda. Semakin banyak indra yang digunakan, semakin banyak dan jelas pengetahuan yang diperoleh. ${ }^{12}$ Media penyuluhan diperlukan untuk menumbuhkan minat belajar, membantu sasaran untuk mengerti lebih baik, mengingat dengan baik dan membantu mengatasi kesulitan bahasa. Media yang digunakan tersebut dapat menunjang pemberian materi yang disampaikan melalui ceramah. Penggunaan media peraga dalam penyampaian pendidikan pada siswa akan menarik dan memberikan motivasi belajar yang tinggi. ${ }^{15}$

Pada penelitian ini, peningkatan nilai rata-rata cakupan pada kelompok eksperimen lebih besar dari kelompok kontrol. Kelompok eksperimen mengalami peningkatan 20,48 nilai rerata dari pretest 70,40 menjadi 90,88 pada posttest. Belajar adalah upaya mengubah kemampuan pembelajar yang tidak sadar bahwa diri tidak tahu, menjadi sadar bahwa sesungguhnya tidak tahu kemudian belajar menjadi sadar dan tahu. ${ }^{23}$ Metode pendidikan kesehatan dengan penyuluhan membuat proses belajar berlangsung dengan memanfaatkan semua alat indra, tetapi alat indra yang terbanyak menyalurkan pengetahuan ke otak adalah mata. Sekitar $75-87 \%$ dari pengetahuan manusia diperoleh melalui mata, sedangkan indra lain hanya $13-25 \% .{ }^{24}$

Kedua kelompok responden berhasil melakukan tiga hal dalam proses mengingat dan belajar meliputi mendapatkan, menyimpan sebelum posttest sekitar 20 menit dan mengeluarkan kembali dengan mengisi kuesioner. Tidak lama setelah menghafal ingatan mengalami penurunan tajam. Retensi ingatan baru cukup stabil ketika isi ingatan tinggal sedikit. Persentase bahan yang teringat 20 menit setelah belajar sekitar 53\% dan cara terbaik untuk memahami adalah melalui pertanyaan. ${ }^{25}$ Responden kelompok eksperimen berhasil mengalami proses belajar, pengetahuan setelah belajar tersebut dapat dilihat dengan peningkatan pengetahuan yang lebih baik pada posttest karena di dalam kegiatan penyuluhan responden banyak melakukan diskusi dengan pemateri.

\section{Kesimpulan}

Terdapat perbedaan rata-rata nilai pengetahuan pada kelompok eksperimen dan kelompok kontrol pada siswa kelas VIII SMPN 1 Patuk tahun 2013. Terdapat pengaruh penyuluhan dengan peningkatan pengetahuan tentang pernikahan usia muda tahun 2013. Metode penyuluhan tersebut dapat dijadikan pilihan bagi pelaksanaan pemberian pendidikan kesehatan untuk meningkatkan pengetahuan siswa tentang pernikahan usia muda.

\section{Saran}

Pelaksanaan pendidikan dan program kegiatan di bidang kesehatan reproduksi remaja khususnya tentang pernikahan usia muda diharapkan menggunakan metode pendidikan kesehatan berupa penyuluhan dengan berbagai media atau alat peraga. 


\section{Daftar Pustaka}

1. Badan Kependudukan dan Keluarga Berencana Nasional. Grand design pengendalian kuantitas penduduk 2010-2035. Jakarta: Badan Kependudukan dan Keluarga Berencana Nasional; 2011.

2. Badan Kependudukan dan Keluarga Berencana Nasional. Bahaya, program KB “jalan di tempat”. Jakarta: Badan Kependudukan dan Keluarga Berencana Nasiona 1; 2013 [diakses tanggal 1 Februari 2013]. Diunduh dari http://www.bkkbn.go.id/ViewBerita.aspx?BeritaID=703.

3. Badan Pusat Statistik Provinsi Daerah Istimewa Yogyakarta. Statistik kesejahteraan rakyat 2011. Yogyakarta: Badan Pusat Statistik Provinsi Daerah Istimewa Yogyakarta; 2012.

4. Badan Penelitian dan Pengembangan Kesehatan Kementerian Kesehatan Republik Indonesia. Riset kesehatan dasar 2010. Jakarta: Kementerian Kesehatan Republik Indonesia; 2010.

5. Badan Kependudukan dan Keluarga Berencana Nasional. Kajian pernikahan dini pada beberapa provinsi di Indonesia. Jakarta: Badan Kependudukan dan Keluarga Berencana Nasional; 2012.

6. Fadlyana E, Larasaty S. Pernikahan usia dini dan permasalahannya. Jurnal Sari Pediatri. 2009; 11(2): 136-40.

7. Badan Pusat Statistik, ORC Macro. Indonesian young adult reproductive health survey 2002-2003. Calverton, Mayrland, USA: Badan Pusat Statistik and ORC Macro; 2004.

8. Badan Pusat Statistik. Angka fertilitas total menurut provinsi 1971 2010. Jakarta: Badan Pusat Statistik; 2010 [diakses tanggal 31 Desember 2013]. Diunduh dari dari : http://www.bps.go.id/eng /tab_sub/view.php?tabel=1\&daftar=1\&id_subyek=12\&notab=7

9. Badan Kependudukan dan Keluarga Berencana Nasional DIY. 45 orang penyuluh keluarga berencana dan kader mengikuti pelatihan pembuatan peta keluarga di balai pelatihan dan pengembangan Badan Kependudukan dan Keluarga Berencana Nasional DIY. Yogyakarta: Badan Kependudukan dan Keluarga Berencana Nasional DIY; 2013 [diakses tanggal 31 Desember 2013]. Diunduh dari: http:/ /yogya. bkkbn. go. id/ View Berita. aspx? BeritaID=1650.

10. Kementerian Agama Kantor Wilayah Provinsi Daerah Istimewa Yogyakarta. Daftar laporan nikah, talak, cerai dan rujuk tahun 20102012. Yogyakarta: Kementerian Agama Kantor Wilayah Provinsi Daerah Istimewa Yogyakarta; 2012.

11. Kantor Urusan Agama Kecamatan Patuk. Daftar pernikahan, rujuk, talak dan cerai menurut umurnya tahun 2011-2012. Gunungkidul: Kantor Urusan Agama Kecamatan Patuk; 2012.

12. Notoatmodjo S. Promosi kesehatan \& ilmu perilaku. Jakarta: Rineka
Cipta; 2007.

13. Emilia O. Promosi kesehatan dalam lingkup kesehatan reproduksi. Yogyakarta: Pustaka Cendekia; 2008.

14. Rahmadiliyani N, Hasanbasri M, Mediastuti F. Kepuasan siswa SLTA terhadap penyuluhan kesehatan. Jurnal Berita Kedokteran Masyarakat. 2010; 26 (4): 203-10.

15. Ricketts SA, Guernsen BP. School-based health centers and the decline in black teen fertility during the 1990s in Denver, Colorado. American Journal of Public Health. 2006; 96: 1588-92.

16. Amarasuriya H, Goonesekere S. Emerging concerns and case studies on child marriage in Sri Lanka. Sri Lanka: United Nations Children's Fund; 2013.

17. Berhane F, Berhane Y, and Fantalun M. Adolescents, health service utilization pattern and preferences: Consultation for reproductive health problems and mental stress are less likely. The Ethiopian Journal of Health Development. 2005; 19(1): 29-36.

18. World Health Organization. Adolescent-friendly health services in the South-East Asia Region. Report of a Regional Consultation 9-14 February 2004, Bali, Indonesia. New Delhi: World Health Organization Regional Office for South-East Asia; 2004.

19. L'Engle KL, Brown JD, and Kenneavy K. The mass media are an important context for adolescents' sexual behavior. Journal of Adolescent Health. 2006; 36(3): 186-92.

20. Mubarak WI, Chayatin M, Rozikin A, Supradi. Promosi kesehatan sebuah pengantar belajar mengajar dalam pendidikan. Yogyakarta: Graha Ilmu; 2007.

21. World Health Organization. The sexual and reproductive health of younger adolescents. 2011 [diakses tanggal 3 Februari 2013]. Diunduh dari: http://whqlibdoc.who.int/publications/2011/9789241501552_ eng.pdf

22. Narendra MB, Sularyi TS, Soetjiningsih, Suyitno H, Ranuh IGN. Tumbuh kembang anak dan remaja. Jakarta: Sagung Seto; 2002.

23. Darmiastuty M. Efektivitas metode ceramah tanya jawab dan simulasi dalam meningkatkan pengetahuan dan sikap ibu tentang pencegahan dini penyalahgunaan narkoba pada remaja di SLTP 1 Borobudur Kabupaten Magelang [tesis]. Semarang: Universitas Diponegoro; 2003.

24. Mahfoedz I, Suryani E. Pendidikan kesehatan bagian dari promosi kesehatan. Yogyakarta: Fitramaya; 2007.

25. Naga SD, Wismaningsing N, Marat S, Zahra RP, Waruwu FE, Satiadarma MP. Belajar dan lupa: tantangan bagi pembelajaran. Jurnal Provitae. 2005; 1(2): 1-6. 